\title{
MANAGEMENT OF COMMONS AS A TOURISM RESOURCE: CASE STUDY OF THE DARANGYI PADDY IN GACHEON, NAMHAE, SOUTH KOREA
}

\author{
Jung NAM-SICK* \\ Mokpo National University, Department of Urban and Regional Development, 1666, Yeongsan-ro, \\ Cheonggye-myeon, Muan-gun, Jeollanam-do 58554, Korea, e-mail: for2018@hanmail.net
}

\begin{abstract}
Citation: NAM-SICK, J. (2020). MANAGEMENT OF COMMONS AS A TOURISM RESOURCE: CASE STUDY OF THE DARANGYI PADDY IN GACHEON, NAMHAE, SOUTH KOREA. GeoJournal of Tourism and Geosites, 28(1), 175-190. https://doi.org/10.30892/gtg.28114-461
\end{abstract}

\begin{abstract}
This study examines the management characteristics of the Darangyi paddy commons, a tourism resource in South Korea under the management of local communities. Through fieldwork and on-site interviews, this study reveals how the Darangyi paddy is managed and utilized by the community. It verifies Ostrom's eight principles of commons management and confirms the need for the concretization of social boundaries for supply and demand regarding commons as well as the need for preparing community-centered conflict resolution and resident participatory communication mechanisms to improve cooperation. The resources are created by the community, requiring government support to operate and integrate tourism resources.
\end{abstract}

Key words: tourism commons, community, Ostrom, cooperative plan, Darangyi paddy

\section{INTRODUCTION}

In South Korea, various commons historically managed by local communities are being used as tourism resources through capital investment and government intervention. Local resources transformed into tourism resources include forests, rivers, sea-fishing grounds, and scenic sites, in which residents have large stakes. However, the influence of independent community organizations in the actual operation and management of the commons is weakening. As the number of participating communities dwindle, commons managed by local communities are emerging, as new challenges must be solved to ensure sustainability, such as disappearing forests and ecosystems, unmanaged rivers, closed seafishing grounds, and damage to scenic agricultural sites because of exploitation. Thus, public policies are now necessary to manage resources and develop both new roles and relationships among community members to address the lack of community participation in the management of commons, which have historically been formed by residents through exchanges. Policy preparation requires reflection on history. Historically, tourism resource development projects utilizing commons adhered to policy objectives or capital interests. In

\footnotetext{
* Corresponding author
} 
this process, communities have played a limited role as opinion makers rather than as decision makers. The difficulty in establishing relationships with communities as project entities is the main reason a tourism development project using local resources, in this case, commons, is considered a market failure. The perspective regarding commons as an object of a tourism resource development project requires a new interpretation. Since Hardin (1968) emphasized the importance of the economic marketability and national management of environmental resources, there has been ongoing research on the limitations of the heterogeneous nature of utilization and preservation (Healey, 2003; Helfrich, 2014).

These concerns can be understood in the context of utilizing environmental resources that focus on maximizing profits through empirical behaviors, which should be accompanied by joint management efforts to solve problems through trust-based interaction. Previous studies on commons utilization and preservation emphasize strategic interaction in human decision-making. Specifically, the model of Hardin (1968), a leading researcher on commons, is meaningful because it clearly presents the roles of humans in resource management. However, one of its limitations is that it generalizes various commons situations, which are formed given the unique characteristics of regions and social exchanges. The selfishness of humans may not be universal in the historical context; thus, the contexts of specific individuals and societies need to be examined in detail. As a society develops and diversifies, people face various situations that require them to overcome conflicts through individual interactions. Contrary to Hardin's (1968) predictions, many studies have found that people cooperate to solve specific problems and even make sacrifices (Arnstein, 1969; Steers, 1991; Healey, 2006; Lee, 2009; Choe \& Kim, 2014; Kim \& Kwon, 2016).

Many social science studies present evidence that supports the conclusion that human behaviors are not motivated by economics alone. In other words, cooperation, love, sacrifice, and honor can be more important motivators than economic profits to inspire actions (Polanyi, 1957; Ostrom, 1990; Kim, 2014; Kip, 2015; Jung, 2016). Examples of commons being managed as joint financial, tourism, and recreational resources under the participation and interest of local communities are increasing.

This study, through fieldwork and on-site interviews, reveals how the Darangyi paddy tourism resources in the Gacheon Darangyi Village in Namhae-gun, Gyeongsangnam-do, is managed and utilized by the community.

Policy implications and recommendations are then revealed. The Darangyi paddy has been designated as a Korean scenic site, number 15, and described by CNN as one of the must-visit places in South Korea (Son \& Kim, 2016). Thus, it possesses strong characteristics of a commons in East Asia, preserved for its historical as well as scenic and environmental values. Specifically, this study verifies the eight principles of commons management proposed by Ostrom (1998), a leading commons scholar. This work is meaningful because it empirically reveals the relationship between local resources, which strongly correspond to commons, and local communities that are required to develop and operate tourism, which strongly corresponds to the economy.

\section{BACKGROUND AND ANALYTICAL FRAMEWORK Characteristics of Commons}

Commons, or common pool resources, are natural or artificial facilities characterized by non-excludability and subtractability (or rivalry), and that can be shared or used by many individuals (Ostrom, 1990). Non-excludability means that people cannot be prevented from accessing commons; more specifically, preventing access is expensive. Subtractability means that the amount of available resources reduces as they are used and that the use of 
commons by one person affects the amount available for others to use. Rivalry is another term for subtractability. Anyone can access commons, and their amount decreases with use. Thus, goods or services whose benefits reduce with use are included in commons. Commons are not just natural resources (e.g., water resources, forests, natural landscapes, grasslands, wild animals, rivers, and streams, which are natural resources available for the development of tourism), but also infrastructure (e.g., roads, ports, and radio waves), depending on the interpretation. Historically, air and water are strongly associated with public property that has relatively low rivalry compared with commons. Today, these tend to be classified as property, which is strongly associated with commons, as rivalry for these resources is increasing (Poteete et al., 2010; Briassoulis, 2019).

Most studies of commons hinge on three perspectives. The first is the traditional perspective that considers commons to be shared goods or services. The second perspective includes the communing process. The third perspective considers the entities related to the production and reproduction of commons (Kip, 2015). This perspective can be interpreted as being identical to Helfrich (2014), who claimed that commons do not merely exist but are created. That is, there is a trend of perceiving commons as composite outputs of traditional rules and customs of entities around resources, without limiting them to the morphological aspects of goods or services of specific resources. This analysis suggests that commons do not have fixed forms of resources but rather can be recreated through production and operation management processes. This analysis is the rationale for explaining the role of the community in the operational management of commons, which this study examines, and serves as a theoretical basis for explaining the relationship between the community and commons (Van Laerhoven \& Orstorm, 2007; Wall \& Derek, 2014; Kaivanto, 2018).

Newer perspectives on the concept of commons are being actively researched by environmental and social studies scholars with a keen interest in common pool-resources, such as village forests in agricultural areas, joint ranches in Jeju Island, sea-fishing grounds in fishing villages, and groundwater in water-scarce areas (e.g., Lee \& Kim, 2011; Choe, 2013). These studies reveal that existing traditional management systems are at risk of being dismantled when nations and external capital are involved in common-pool resources that have maintained well-preserved traditions around local communities (Yun, 2006; De Moor, 2008; Kwon, 2012; Choe, 2013; Choe \& Kim, 2014; Yu et al., 2014; Kim \& Jung, 2016; Merino \& Cendejas, 2017; Briassoulis, 2019).

\section{Ostrom's Eight Principles for Managing Commons}

Ostrom (1994) generalized the community management theory of commons through cases of autonomous communities that successfully solve dilemmas about their usage. According to this theory, the sustainability of a community and common pool resources can be maintained if the community satisfies eight principles, which are described in detail below (Araral, 2014; Lee et al., 2014; Mansbridge, 2014; Thiel et al., 2015; Fedreheim \& Blanco, 2017). The first is the principle of clearly defined boundaries. Here, boundaries refer to the physical and social boundaries of various tangible and intangible common pool resources in the community. The second principle is the congruence between appropriation, provision rules, and local conditions.

This principle describes the extent to which institutional devices for local resources consider their characteristics in terms of the physical constraints and circumstances of the resources in the community. The third principle is collectivechoice arrangements. This principle defines the rights of internal groups to create and change the rules or conditions for commons in the local community (Nkoka et al., 2004). The fourth principle is monitoring. Monitoring in the community influences the self-monitoring of members. The fifth principle is graduated sanctions. 
This describes a progressive punitive device for people who do not abide by the rules agreed upon by the community. The sixth principle is conflict resolution mechanisms. Conflicts regarding commons frequently occur among community members because commons are properties that possess the characteristic of rivalry.

The seventh principle is the minimal recognition of rights to organize. The decisionmaking right of community members must be guaranteed by delegation to be protected from external interference. The eighth principle is nested enterprises. This principle was newly added to address the criticism that the existing principles of Ostrom are limited to small communities. Thus, this principle can be regarded as a general condition for large communities with multi-layered organizations (Agrawal, 2001; Gallardo Fernández \& Friman, 2011; Fennell, 2011; Hill et al., 2015; Brenda et al., 2016). As described above, Ostrom's principles for managing commons can also be useful in today's planning process for tourism resources. They can provide valuable clues for designing social governance, especially for commons, which are governed by the coexistence and cooperation of principles in small communities, such as the tourism resources of farming and fishing villages. Specifically, it would be interesting to examine the differences between Ostrom's principles and the historical customs and norms for commons that have been preserved in farming, mountain, and fishing villages in South Korea. However, no study has yet applied Ostrom's principles for managing commons to tourism resources development sites in South Korea (McGrath et al., 2007; Fennell, 2011; Delgado-Serrano, 2015).

\section{RESEARCH METHOD}

\section{Commons Characteristics of Namhae Darangyi Village}

Commons generally have the characteristics of resources that are not owned by individuals or the government; they have low excludability and high rivalry. In this respect, Darangyi paddies are different from the general concept of commons because both individuals and the national government own them. However, even if they were privately owned, Darangyi Village has a traditional pact to uphold, which is to manage the Darangyi paddy. That is, Darangyi paddies also have the characteristics of commons.

For example, when an aloe farm was built in the middle of the Darangyi paddies as a tourism facility or a greenhouse, the villagers opposed them because they could adversely affect the unique landscape of the area. Thus, even if Darangyi paddies were privately owned properties, they would have strong characteristics of commons regarding the landscape being formed jointly with the village. Darangyi Village was designated as a scenic site in 2005. National cultural properties are preserved and managed at the national level. Regardless of their ownership, the Darangyi paddies and its scenic site must be preserved and managed as a public good. That is, they are managed as commons by village rules and under the Cultural Heritage Protection Act (2018).

Historically, there was low awareness about rivalry as a characteristic of commons regarding the scenic site of the Namhae Darangyi paddy. Until tourism development under the traditional rural theme village project was launched, Darangyi paddies were rainfed paddy fields for double cropping by the community, and the resources had no rivalry. In other words, there was no need or obligation to maintain the scenic sites of the paddy fields. Therefore, the scenic resources had the characteristics of a general private property that had no rivalry. Today, they are considered a scenic site that serves as a tourism product.

However, to be used as a tourism property, the existing rain-fed paddy field had to be continuously managed as a Darangyi paddy scenic site. Owing to the modernization of agriculture and the aging of rural communities, supply shortages have become a reality for the site, which was formed by traditional agricultural activities; thus, a rivalry emerged. The 
rivalry in Darangyi paddies appeared around 2005, when they were designated as scenic sites and Darangyi Village has since become a famous tourist destination.

\section{Complementing the Commons Management Principles}

The purpose of this study is to verify the applicability of Ostrom's principles for managing commons to the management process of tourism resources in South Korea. So far, no study has applied Ostrom's principles for managing commons to tourism resource development sites in South Korea. The principles underpinning the management of commons were complemented for the target site through a preliminary survey.

The objective of this preliminary survey was to answer the following questions: Are Ostrom's principles for managing commons applied in the field? What is the appropriate level of difficulty of questions for interviewees? A researcher with 15 years of experience in tourism for farming and fishing villages surveyed 10 leaders and residents of Darangyi Village. The researcher noted their responses on detailed status and Ostrom's eight principles and adjusted the difficulty level of the questions. The survey results had a few important indications. First, regarding clearly defined boundaries, their answers concentrated on physical boundaries. For social boundaries, they understood them in the context of native places or places of residence, such as out-of-towners, tourists, and other villagers, and they did not perceive them as boundaries. This perception can cause many problems, but it may not be recognized as a variable because of the difficulty in responding to the questions. Thus, this part needed to be adjusted. The questions were revised to distinguish between physical and social boundaries. The next questions were about the guarantee of autonomy and collective-choice arrangements. The former question was: were there minimal decision-making rights? The latter question was: is the participation of all members guaranteed? However, it was difficult to distinguish between these two variables because Darangyi Village is a small, natural village comprising around 60 households. Hence, these two variables were integrated into collective-choice arrangements. We verified how Ostrom's principles for managing commons were applied to the cooperative planning process in Darangyi. Furthermore, we examined how cooperatively Ostrom's management principles were planned in each step, as well as the level of resident participation. The examination results were coded for categorization.

\section{In-depth Interview and Content Analysis}

The main data for this study were collected through in-depth interviews with participants as a group, including community leaders and local administrators. To obtain sufficient and realistic data from residents and administrative agencies, we adopted an interview method based on unstructured questions; however, some structured questions were used as well. The interviews were conducted at convenient places regardless of the format and included group interviews, one-on-one interviews, and one-on-two interviews. Before the interviews, we promised the interviewees that we would keep the interview content confidential and use it only for research purposes. Each interview lasted approximately 90 minutes. The interviews were recorded after obtaining prior consent from participants. Coding was performed based on recorded data. In the coding process, local dialects, personal jokes, and incomplete sentences were revised by the researcher. The in-depth interviews were conducted in December 2017. On December 14 and 15, 2017, interviews were conducted with nine members of the Darangyi Paddy Preservation Society. All participants were former or current village heads, Development Committee chairs, or heads of the Preservation Society.

\section{Examination of Laws, Systems, and Reports}

The major disadvantage of interviews with villagers and administrative agencies is that they rely on individual memories. Erroneous information may be conveyed because 
of individual differences in memory; hence, erroneous information may be coded based on the characteristics of the researcher who interprets them. The objectivity of information was improved through laws, systems, reports, and press articles to address this drawback. This measure aimed to ensure the authenticity of the research results and reviews, which would be based on objective data and assisted in addressing the tendency of the researcher to judge interviewees subjectively during the interviews.

\section{RESULTS AND DISCUSSION}

This section describes the final selection results of the community management principles for the Darangyi paddies in South Korea. The selection was achieved through in-depth interviews and a literature review based on Ostrom's eight principles for managing commons with respect to the current state of the target site.

\section{Clearly Defined Physical Boundaries}

All 24 residents who participated in the interviews concerning the boundary setting of the scenic site protection zone clearly remembered the progress of the boundary setting for the Darangyi Village scenic site. Furthermore, they also expressed relatively unified opinions about the roles of the residents and Cultural Heritage Administration in the physical boundary-setting process. Thus, the reliability of the interview content is high. The main content of the interviews is as follows.

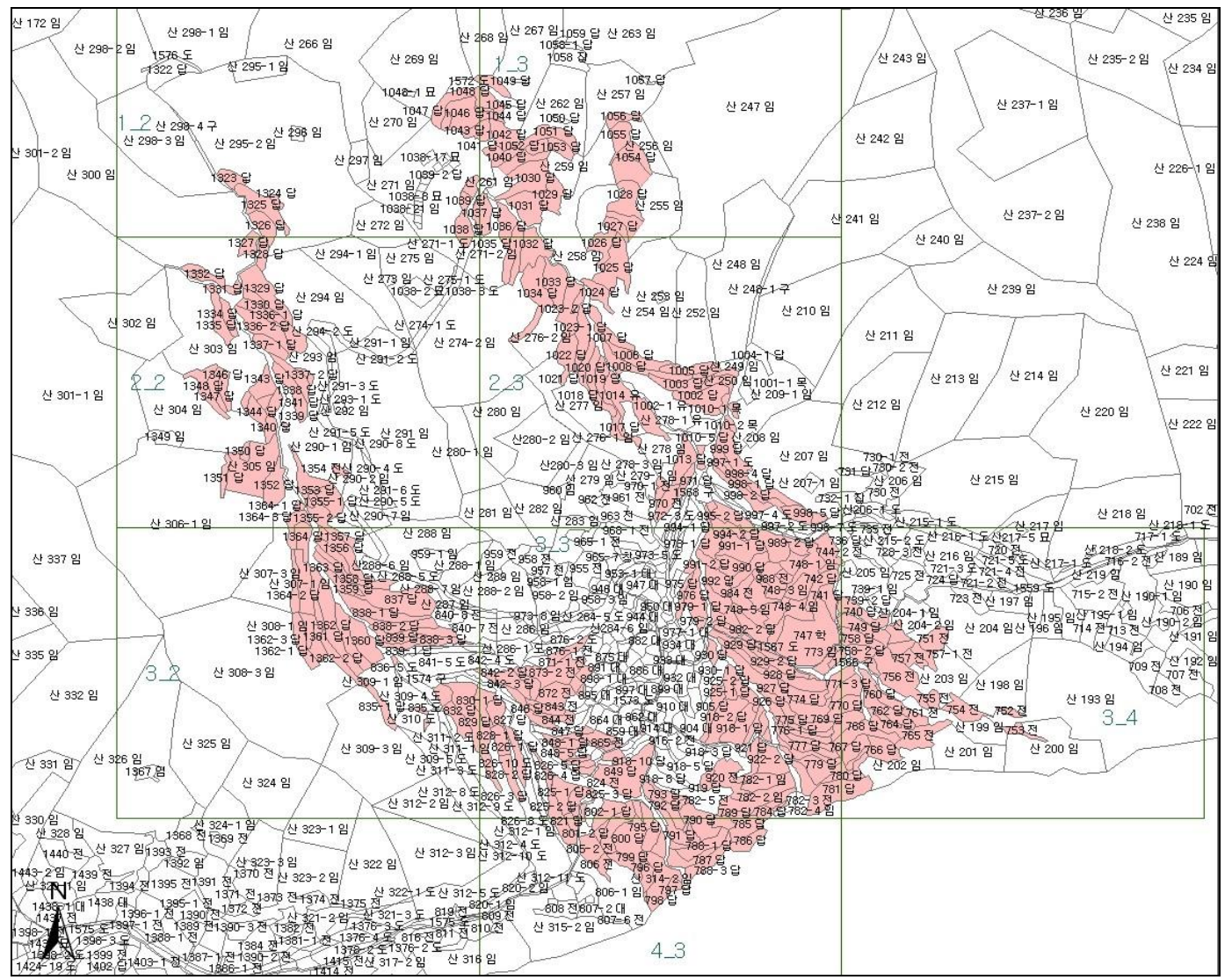

Figure 1. Boundaries of the scenic 
The dominant opinion of residents was that some regulations were necessary to provide a high-quality view of the Darangyi paddies to tourists who visit through the traditional rural-themed village project. Thus, designation as a scenic site was smoothly done in accordance with the process. In this process, the boundaries of the Darangyi Village scenic site were confirmed in January 2005, when residents unilaterally accepted the boundaries suggested by the Cultural Heritage Administration. At the time, the area of the designed site was $195,428 \mathrm{~m}^{2}$ (274 pilji), and this was expanded to $227,554 \mathrm{~m}^{2}$ (304 pilji) in 2008. In other words, the awareness of the physical boundary setting of the scenic site by residents and administrative agencies was confirmed through the in-depth interviews. The clearly defined physical boundaries are also confirmed through the Cultural Heritage Protection Act (Figure 1).

First, Article 13 of this Act (2018) prescribes that a historical and cultural environment preservation area must be placed at least 500 meters from the outer boundary of the designated cultural heritage. According to this criterion, the Namhae Darangyi Village is set 500 meters from the outer boundary of the Darangyi paddy.

Specifically, Darangyi Village is designated as a myeon unit protection zone $\left(227,554 \mathrm{~m}^{2}\right)$ instead of a point-unit protective facility, and the preservation area is set in a 500-meter radius of the protected area's outer boundary. A relatively large residential area with a radius of $800-1200$ meters was designated as requiring permission for altering the current state. When an area such as the Darangyi paddy is designated as a scenic site, protective facilities or protection zones are designed by the Enforcement Decree of the Cultural Heritage Protection Act (2018). However, these are targeted at zones required for scenic site protection, which has some ambiguity and can be interpreted somewhat independently. In the actual process, the designation of paddy as a scenic site was finally notified after field inspection by the technical experts of the Cultural Heritage Committee via a notice of designation. That is, the current Darangyi paddy can be considered a commons with clearly defined physical boundaries established by expert judgment for an area recognized as a protective facility or a protection zone. Moreover, the community clearly recognizes this designation.

\section{Clearly Defined Social Boundaries}

The qualifications of the custodians and users of the Darangyi paddy were investigated during in-depth interviews to examine the social boundary setting of the protection zone in the process of designating Darangyi Village as a scenic site. Most interviewees either had no memories of custodians and users or answered that they did not exist. They answered that most residents cared little about the custodians and users because the Cultural Heritage Administration promised to purchase Darangyi paddies when they were designated as a scenic site. The Cultural Heritage Administration did not initiate any communication with residents in the scenic site designation process because they have no obligation to set social boundaries in the use and management of the scenic site. Thus, there was no clarification on setting user admission fees for visiting the cultural heritage; in addition, there was no clarification on custodians when the entire protection zone for Darangyi Village was purchased. Residents must continue farming in the Darangyi paddies to ensure they are continuously managed as a commons for tourism and recreation activities. Thus, effective communication with Darangyi paddy landowners and farmers should have been undertaken in the scenic site designation process.

Nevertheless, the interviews provided relatively clear answers to the questions about the responsibilities and rights of the regular and associate members of the Village Association and Darangyi Paddy Preservation Society, the traditional organizations in the village. Traces of independent efforts to find solutions to issues regarding social 
boundaries not addressed in the upper-level law were found in the lower systems. For example, resident qualifications were separately provided in the independent rules of the Village Association, and the Darangyi Paddy Preservation Society was established. These examples show the efforts of residents concerned about the paddy custodians.

To further examine the content of interviews with residents and administrators, we reviewed the regulations related to the social boundary setting of the scenic site as prescribed in the Cultural Heritage Protection Act. First, Article 34 of this Act (2018) states that when it is deemed difficult or inappropriate for the custodian to manage the heritage, a local government body, corporation, or organization can be designated as the manager. The Cultural Heritage Administration designated Darangyi Village as a statedesignated scenic site; however, Namhae-gun is the custodian. Therefore, Namhae-gun must fulfill its obligation as a legal custodian. Apart from the guarantee to prescribe custodians and users of the Darangyi paddies, autonomous rules for recognizing villagers of Darangyi Village were also observed. Moreover, regarding the custodians, as defined in the Cultural Heritage Protection Act and ordinances, the Village Association grants the responsibilities and rights of villagers separately for regular and associate members.

Historically, they only recognized residents who have lived in the village for more than five years as regular members; however, this five-year rule was abolished in 2012 to prevent conflict between original and migrant residents. The Darangyi Paddy Preservation Society separately distinguishes between those who own land and reside in the village (regular members) and those who do not live in the village (associate members) in its articles of association (Delgado-serrano, 2015).

\section{Conditions \\ Congruence Between Appropriation, Provision Rules, and Local}

Congruence between appropriation, provision rules, and local conditions refers to the requirement that the rules must be consistent with the social and physical conditions of the community, and the commons must be managed for sustainable supply and demand. Darangyi Village did not discuss these two items in the scenic site designation process. According to the resident responses in the interviews, the farming workforce required to maintain the Darangyi paddies was not planned at the beginning. There are clear differences between the management of Darangyi paddies for livelihood and the management of Darangyi paddies as tourism resources. However, these differences were not discussed. That is, there were no predictions about the supply of and demand for Darangyi paddies. The management of the Darangyi paddy was also difficult because of aging farmers. Many users wanted to engage in a service business (e.g., restaurant, and bed \& breakfast) using the Darangyi paddies; however, interviewees responded that suppliers looking to manage the Darangyi paddies as commons were insufficient in number. Historically, Darangyi paddies were cultivated for livelihood; they must now be cultivated for tourism. Another problem is a mismatched scene that occurs when the stone wall construction technique used by the Cultural Heritage Administration is different from the one used historically by local residents. The differences between the stone walls constructed in accordance with the stonework specification of the Cultural Heritage Administration and those traditionally built by villagers are visually glaring. According to the stonework specification of the Cultural Heritage Administration (2014), the stones are piled through frosted work, chiseled work, bush-hammered stone finishing, dabbed finish, and rubbing with water.

However, residents naturally pile up the stones gathered from the surroundings without these processes. Most interviewees think that the management method of the current Darangyi paddy stone wall does not work well with the local conditions. 
Thus, to verify this, we examined the stonework manual (2014) in the standard specifications for cultural heritage repair. The specifications introduce stonework methods for various cultural heritage sites. For the Namhae Darangyi paddy stone walls, they used random and dry masonry according to the stonework standards. Specifically, for dry masonry, they ensured a large contact area to enlarge the surface friction because of the method's nature. However, when the front surface of stones is finished, it creates a different view from that produced in the traditional method used by residents.

The use of agricultural water also differs with the local conditions. Some storage is required to supply water to the paddies, but it is difficult to develop new water storage facilities in the cultural heritage protection zone, thereby causing differences in the local circumstances. The Darangyi paddies have the characteristic of a rain-fed paddy field, and locals naturally stopped farming when the water was insufficient. However, when it was designated as a scenic site, agricultural water for managing the designated area as paddies became insufficient. Before the designation, the site could be left fallow because the paddy fields were rainfed. However, under the current system, it is difficult to leave the site fallow. This is another discrepancy between the local circumstances and the provision rules. Regarding agricultural water, we reviewed the Cultural Heritage Protection Act (2018) and the designation notification. Storage must be installed outside zone 3 based on the permission criteria for the alteration of the current state to secure the water storage required for the management of the Darangyi paddy. This means that farmers must supply water from a reservoir $1.3 \mathrm{~km}$ away. There is an imbalance between supply and demand because few residents want to persist with the difficult farming method to maintain the view of the unprofitable Darangyi paddies.

Darangyi Village has not solved the problem of correspondence between the farming workforce and management area of the Darangyi paddy, or the agricultural water supply problem in the scenic site designation process. Since 2013, water has been supplied to the farming workforce through the Darangyi Paddy Preservation Society, but more than $60 \%$ of the site remains fallow. This phenomenon seems to be caused by the designation of an area as a scenic site, which exceeds the management scope of Darangyi Village. The suffrage of residents using the Darangyi paddies is guaranteed under the establishment and revision of the utilization rules of the Darangyi Paddy Preservation Society, which has been created independently by villagers.

Although this suffrage does not solve the intrinsic problems of the Darangyi paddy utilization rules, the communication channel of the Darangyi Paddy Preservation Society plays a mediating role between the administrative agencies and residents. Consequently, the Darangyi Paddy Preservation Society plays a significant and predictable role in managing the Darangyi paddy fallow field problem.

Hence, to examine the interviews of residents and administrators in more detail, we analyzed the Cultural Heritage Protection Act and articles of association of the Darangyi Paddy Preservation Society. The establishment and revision of the Cultural Heritage Protection Act is the responsibility of the National Assembly and administrative department and is not discussed in this study. Thus, we checked the extent to which the suffrage of residents was guaranteed in the designation, management, and operation of the Darangyi paddies. The qualifications of the Cultural Heritage Committee restrict the participation of general residents because most qualifications are defined in terms of education, expertise, and experience in specialized areas. Moreover, the exclusion conditions regarding member qualifications and the provision that only interested parties related to cultural heritage can be members of the committee make it practically impossible for scenic site villagers to participate in the 
committee. By contrast, the Darangyi Paddy Preservation Society, established voluntarily by the residents of Darangyi Village and supported by the local government, ensure the suffrage of villagers. The suffrage of residents regarding membership qualifications, suffrage, and dissolution rights is guaranteed. However, there are limitations in actively coping with important issues such as the supply, utilization, boundary setting, and restriction on actions regarding the Darangyi paddies because the Preservation Society was established to manage the financial support projects of the Darangyi paddies efficiently. The crisis in managing the Darangyi paddies has weakened to some degree through the establishment of the Darangyi Paddy Preservation Society.

In 2012, nearly $92 \%$ of the paddies were fallow. Currently, however, it is managed at a $60 \%$ level. Although the organization has no right to establish and revise the Darangyi paddy utilization rules, the existence of suffrage organized and granted by the community presents a new direction for the management of the Darangyi paddy.

\section{Collective-choice Arrangements}

The in-depth interview questions in this section focus on the process of agreement on major agenda items to find the degree to which the opinions of residents can be collected for the management of the Darangyi paddy by the Cultural Heritage Protection Act, which is an upper-level law. Even now, 14 years after designation as a scenic site by the Cultural Heritage Protection Act, residents' opinions about the designation are mixed. Some have a positive opinion that the designation as a scenic site has increased tourists, diversified economic activities, and prevented the thoughtless development of the Darangyi paddies. Others have negative opinions about increased competition among residents, reduced generosity of villagers, and disadvantages in exercising property rights.

Given the suffrage of villagers about the establishment of a revision of the utilization rules for scenic site designation, the operation and management of the Darangyi paddies are not being guaranteed. However, there was a provision for Namhae-gun and the Cultural Heritage Administration to accept some requests through the Cultural Heritage Committee when villagers collect and present a unanimous opinion about partial adjustments to the scenic site boundaries or seek more active management activities from Darangyi paddy custodians. The scenic site boundaries have been changed twice in the past 14 years, and Namhae-gun has actively supported the establishment of the Preservation Society for the management of the Darangyi paddy. Consequently, the suffrage of villagers regarding the utilization and management of the Darangyi paddies has not increased; however, the existence of some communication channels in the project implementation process has been confirmed.

\section{Monitoring}

Ostrom (1998) asserted that the utilization and management of commons by users must be monitored. This study examined monitoring on two major issues regarding the utilization and management of the Darangyi paddies. The first issue is the existence of the provisions related to the monitoring of users in the Cultural Heritage Protection Act, and the second issue is the existence of rules about monitoring in the autonomous village organization. Most residents did not have accurate knowledge about the monitoring provisions in the Cultural Heritage Protection Act; thus, we checked with the Ministry of Government Legislation. The promises that must be kept among the users in the autonomous village organization were confirmed, but there was no adequate method for confirming the existence of the monitoring suggested by Ostrom. The only data for estimation consists in the interviews with villagers.

The question about the existence of monitoring in an autonomous organization can be burdensome for villagers. Thus, we tried to infer the existence of monitoring 
through indirect questions such as "What do you do if neighboring guests make noise late at night?" and "Is there a provision for supplying water to the paddies?"

Consequently, we estimated some monitoring in Darangyi Village, where 61 households, living close to each other, rely on traditional customs; although there are no documentary regulations, there is monitoring by residents in the same living space. Thus, monitoring among villagers exists as a way of life. When someone violates the rules, they are advised, or when a problem is detected, an elder in the village is asked to solve it. Such constant monitoring is a critical rule in Darangyi Village.

Regulating or monitoring activities for tourist behavior also works. Darangyi Village experiences severe conflicts between villagers and tourists caused by disagreements about the permitted scope of tourist activities and the preservation scope of farming activities. The perception of the Darangyi paddies for personal farming activities collides with the perception that they are public tourism resources. Residents monitor the behavior of tourists on their own and try to control them. However, this conflict is difficult to resolve unless rules aimed at regulating the behavior of tourists in industrialized scenic sites such as Darangyi Village change. The violation of rules in the community can be detected through monitoring and can be easily solved. When visitors violate rules, such behaviors may be monitored; however, there are limitations because many people make continuous use of the site, and, thus, it is somewhat uncontrollable.

The rules to monitor and regulate visitors are difficult, as they are established through the community's autonomous rules. Hence, the Cultural Heritage Protection Act, an upper-level law, should provide an alternative solution. Article 44 of the Cultural Heritage Protection Act (2018) prescribes the obligation for regular investigation of the current state, management, and repair of state-designated cultural heritage as well as other conditions of environmental preservation. The Cultural Heritage Administration investigates the Darangyi paddies every five years. However, it entrusts the actual investigation to an external specialist agency. Monitoring was important in many of Ostrom's case studies because villagers are the monitoring entities. In the Cultural Heritage Protection Act, the obligation for regular investigation has the character of a resource survey centered on custodians rather than residentcentered monitoring (Ostrom, 1991; Lee, 2009; Choe \& Kim, 2014; Helfrich, 2014).

There were no rules for monitoring among the autonomous rules of the village, as mentioned above, although there were documentary rules about sanctions. The autonomous village rules mention incineration, breach of public order, and waste collection as duties that must be fulfilled by villages, but not the monitoring entities that must supervise them. However, all villagers participate in the monitoring activities regarding actual sanctions. As described above, these monitoring activities seem to be carried out conventionally by traditional customs and social relationships.

\section{Graduated Sanctions}

Ostrom (1991) explained that progressive punishments for deviant behavior by users are important factors for the sustainable management of commons by the community. That is, Ostrom believed that sanctions for violators of rules on the use of commons influence the sustainability of resource management. There are no provisions for progressive punishment in the Cultural Heritage Protection Act. In South Korea, the punishment level is generally determined by the explicit damage to and implicit pain of the victim. Punitive damage was acknowledged until the $18^{\text {th }}$ century before systematic social control was established. At the beginning of the modern country, compensatory damage was adopted as a basic principle, which does not distinguish between intention and fault (Han, 2015). Thus, there is no basis for graduated sanctions in the current 
legislation. However, progressive punishment provisions may exist in the autonomous agreements of traditional organizations, such as autonomous village rules and the articles of association of the Preservation Society. Thus, on the question of the existence of graduated sanctions in the autonomous village rules and articles of association of the Darangyi Paddy Preservation Society, as well as the Bed and Breakfast Association, most participants mentioned the three-strike rule of the latter.

As Darangyi Village became a tourist attraction and demand for bed and breakfasts have increased, original and migrant residents scrambled to operate restaurants and bed and breakfasts. From 2003-2010, Darangyi Village became known to outsiders through village experience programs and the designation of the place as a scenic site. As residents competed for independent economic activities rather than village profits from the commons, the village experience program, which was a joint project among villagers, started to shrink. The number of participants in the experience program was 54,000 in 2008, but this dropped sharply to around 5,000 in 2013 . Although the participants of the experience program decreased, over 200,000 tourists visited the village and competition among villagers began earnestly. Owing to this competition, the village entered a period of recession in 2012 and 2013. As it concentrated on individual economic activities, joint projects, such as Darangyi paddy management and the farming village experience program, stagnated and the service quality of restaurants and bed and breakfasts went down because of the competition among farms. This situation resulted in a low tourist satisfaction rate. Darangyi Village faced a crisis during this period, as large pension businesses were built in Honghyeon-ri, a neighboring area. With a keen awareness of the crisis, the villagers decided to act.

They established the Darangyi Paddy Preservation Society to revive the Darangyi paddy scenic site and improved the bed and breakfast and restaurant services through the introduction of the three-strike rule. These decisions decreased fallow Darangyi paddies, and bed and breakfast and restaurant operators began to provide services at a certain level to satisfy the tourism needs of consumers, in accordance with the rules established by the village. Residents responded that mutual promises, such as the three-strike rule, are provided in the articles of association of the Bed and Breakfast Association, but the related provisions do not exist therein. However, the Service Quality Improvement Plan published in December 2012 stated that when guest complaints about the prices and services of a bed and breakfast are received three or more times, it is prevented from taking reservations. We could not confirm the final decision because there were no detailed minutes of the meetings. However, inferring from the interviews and general meeting documents, it was estimated that the threestrike rule had been approved at the general meeting and is being implemented.

\section{Conflict Resolution Mechanisms}

Darangyi Village has pursued various government-supported projects, starting with the traditional rural theme village project in 2002. Various conflicts occurred in this process, as mentioned above, which have been addressed and managed well, and the village projects are currently being implemented in a relatively stable manner.

Traditional villages must have conflict management and resolution mechanisms to maintain relationships among villagers. Based on the interviews, the conflict resolution mechanism on which the majority of residents depend was found to be the Senior Citizens Association. This is a community of elders, and most members have worked in the past as village heads, Saemaul (new town) leaders, and chairs of the Preservation Society. They can serve as rational moderators, and residents said they trusted them. Ostrom also mentioned the importance of conflict resolution mechanisms. If such a mechanism takes 
too much time or is costly, it is difficult to use. However, Darangyi Village is quickly resolving conflicts at a lower cost through the Senior Citizens Associations.

The village rules include provisions for rewards and punishment, but applying sanctions is challenging. However, when a person needs to be sanctioned, it is carried out through the Senior Citizens Association. Since the Association consists of village elders, residents tend to accept its decisions. Nevertheless, there is no conflict resolution mechanism at the administrative agency level in the Darangyi paddy utilization and management processes. Article 3 of the Enforcement Decree of the Cultural Heritage Protection Act (2018) includes local residents among the people from whom opinions should be collected for the establishment of the basic plan for cultural heritage; however, this inclusion seems to be a feedback mechanism rather than a conflict resolution mechanism. The City/Do Cultural Heritage Committees based on Article 71 of the Cultural Heritage Protection Act (2018) are deliberative bodies for the preservation, management, and utilization of local cultural heritage, and it is difficult to consider them as conflict resolution mechanisms. Furthermore, the Darangyi Paddy Preservation Committee installed by Namhae-gun for the preservation and management of Darangyi paddies serves as a consultation body for the administrative agencies regarding the Darangyi paddy rather than as a conflict resolution mechanism. It is prescribed that the representative of Darangyi Village should also participate as a committee member. However, after two or three meetings since its establishment in May 2013, regular meetings have not been held unless there is a special situation.

\section{Nested Enterprises}

The most important condition for community-centered commons management is dialog and trust within the community. The conflict resolution mechanism centering on the Senior Citizens Association is a dialog and trust process that has been built among community members as the result of an ancient tradition. However, as the community grew, it became difficult to guarantee the persistence of dialog and trust. Ostrom insisted on the importance of small groups when suggesting the principles for managing commons because she had a concern about the community size at which the dialog and trust process can work. The Namhae Darangyi Village is a small village with a total population of 108 and 61 households as of 2017. Thus, it does not have a problematic decision-making structure that could occur when a community becomes too large, which was Ostrom's concern. On the contrary, the village has many small groups relative to the community size (e.g., Village Association, Women's Society, Youth Group, Senior Citizens Association, Bed and Breakfast Association, Preservation Society, and Development Committee). Each person participates in two to four organizations. Interviewees responded that these concurrent activities because of the small community size allow them to play a mediating role when there are conflicts between organizations. They cannot unilaterally represent the position of one organization because of the concurrent activities. Even if they do not belong to other organizations, their family members likely belong to them. Thus, the possibility of escalating conflicts among small groups is low.

Our review of the related reports were consistent with the interviews of residents. The Village Association, Senior Citizens Association, Youth Group, and Women's Society were in operation as traditional village organizations, and the Bed and Breakfast Association, Development Committee, and Darangyi Paddy Preservation Society were in operation as business organizations. Among them, the Village Association, Senior Citizens Association, Youth Group, Women's Society, and Preservation Society made decisions through regular meetings. On the contrary, the Bed and Breakfast Association and Development Committee had irregular meetings and a temporary organizational structure. 


\section{CONCLUSIONS}

This case study identifies the need for community-centered commons management policies to serve as measures to overcome the limitations of tourism resources development and commons management policies centered on the nation and market. Based on Ostrom's commons management theory, the commons management principles of the Darangyi paddies in Namhae were analyzed. Consequently, several useful conclusions were derived. First, the importance of low-cost conflict resolution mechanisms was confirmed. Continuous communication through the Senior Citizens Association and Village Association, facilitated by bonding social capital, led to swift and highly cost-effective conflict resolution mechanisms. Accordingly, it was confirmed that low-cost conflict resolution mechanisms are useful tools for managing commons. Therefore, further research on the formation and usefulness of bonding social capital and its interaction with bridging social capital is necessary.

Second, appropriate social boundaries need to be established for the supply and utilization demands of commons. Supply and demand designs of commons are required, such as the designation of a management area appropriate for the abilities of the community or the provision of community management abilities corresponding with the designated or managed area. In the case of Darangyi Village, the final analysis failed to forecast supply and demand. The occurrence of fallow fields every year was because of failed demand predictions by custodians. Some fallow fields are controlled through the Darangyi Paddy Preservation Society; however, the capacity of the local community is insufficient to take responsibility of over $60 \%$ of the fallow fields. Thus, institutional support mechanisms are required for entities producing commons such as the Darangyi paddies and the management culture of the commons that they have created.

Third, commons management principles need to be localized. According to the Cultural Heritage Protection Act, the same rules are applied to the Namdaemun Gate, which is architectural, and Darangyi paddies, which are scenic agricultural sites. In particular, the Cultural Heritage Protection Act lacks consideration for the scenic industrial sites formed by community activities. Further research is necessary on the establishment of local ordinances, the change in management policies in accordance with the characteristics of the resources, and the application of appropriate management rules for local areas. Fourth, the future development of tourism resources should focus on communities and their resources rather than the nation or corporations. The Korean tourism industry has developed through the active intervention of the government, as with Korean economic growth. Local tourism resources have public value. Therefore, we cannot reject government intervention to maintain and preserve public value.

Nevertheless, it is critical for the government to make adequate judgments on the areas of intervention and invest resources at the right time. Local communities should be the main agent in the development of tourism resources, and the government must actively support them. The ultimate goal of the development of tourism resources using commons is to stimulate the local economy and integrate communities. Fifth, various institutional supports are required for the development and management of tourism resources because commons consist of tangible entities and intangible activities. The commons, which are objects of the development of tourism resources, have generally been used as market properties or managed as public properties. Local communities, which must serve as custodians, have used local resources to satisfy the greed of individuals or have been indifferent to them while unilaterally being dependent on the administration.

In this process, the customs and rules between the community and commons have been replaced with laws and regulations. Traditionally, tourism resources development 
policies based on economic growth have been effective. In the future, however, we should concentrate our efforts on tourism resources development policies centered on communities and cooperation. Furthermore, the perspective of commons needs to change to a community-centered one. Lastly, the management principles found in the Darangyi paddies were the customs and rules that residents have traditionally created through cooperation and communication; planners or administrators did not plan them. This kind of resident-led planning process is called a cooperative plan. The power of the community to create principles for managing its resources comes from the advantages of this cooperative planning method. Therefore, new research on the cooperative planning method should be initiated to establish community-centered principles for managing commons. These findings cannot be generalized because of the small sample and focus on one site; thus, other researchers could examine these issues at other sites.

\section{REFERENCES}

Agrawal, A. (2001). Common property institutions and sustainable governance of resources, World Development, 29(10), 1649-1672.

Araral, E. (2014). Ostrom, Hardin and the commons: A critical appreciation and a revisionist view, Environmental Science and Policy, 36, 11-23.

Arnstein, S. R. (1969). A ladder of citizen participation, Journal of the American Planning Association, 35(4), $216-224$.

Briassoulis, H. (2019). The Catharsis of the Commons. International Journal of the Commons, 13(2), $1092-1111$. http://doi.org/10.5334/ijc.969.

Bushouse, B. K., Never, B. \& Christensen, R. K. (2016). Elinor Ostrom's Contribution to Nonprofit and Voluntary Action Studies. Nonprofit and Voluntary Sector Quarterly, 45(4S), 7S-26S.

Choe, H. (2013). The concept of common resources and the joint ranch of Jeju: Characteristics as a common resource, Economy and Society, 98, 12-39. https://www.kci.go.kr/kciportal/ci/sereArticleSearch/ ciSereArtiView.kci? sere Article Search Bean.artiId=ARToo1774447.

Choe, H., \& Kim, S.P. (2014). Wind in Jeju: The management method adopted common pool resources theory, Tamla Culture Research Institute, 46, 97-126. https://www.kci.go.kr/kciportal/ci/sereArticleSearch/ ciSereArtiView.kci? sere Article Search Bean.artiId=ARTo01893969.

De Moor, M. (2008). The silent revolution: A new perspective on the emergence of commons, guilds, and other forms of corporate collective action in Western Europe, IRSH53 (Supplement), 179-212.

Delgado-Serrano, M., del, \& Ramos, P. (2015). Making Ostrom's framework applicable to characterise social ecological systems at the local level, International Journal of the Commons, 9(2), 808-830. https://doi.org/10.18352/ijc.567.

Fedreheim, G. E. \& Blanco, E. (2017). Co-management of protected areas to alleviate conservation conflicts: Experiences in Norway. International Journal of the Commons, 11(2), 754-773. http://doi.org/ 10.18352/ijc.749.

Fennell, L. A. (2011). Ostrom's Law: Property rights in the commons. International Journal of the Commons, 5(1), 9-27. http://doi.org/10.18352/ijc.252.

Gallardo Fernández, G. L. \& Friman, E. (2011). New marine commons along the Chilean coast - the management areas (MAs) of Peñuelas and Chigualoco. International Journal of the Commons, 5(2), 433-458. http://doi.org/10.18352/ijc.284.

Han, T. (2015). Review of possibility of punitive damage system adoption: Expected problem and measures, Doctor Degree of Yonsei University. http://www.riss.kr/search/detail/DetailView.do?p_mat_type= be54d9b8bc7cdbo9\&control_no=1b2ee697c1724608ffeobdc3ef48d419

Hardin, G. (1968). The tragedy of the commons. Science, 162(3859), 1243-1248.

Healey, P. (2003). Collaborative planning in perspective, Planning Theory, 2(2), 101-123.

Healey, P. (2006). Collaborative planning: Shaping places in fragmented societies ( $2^{\text {nd }}$ ed.), Basingstoke: Palgrave Macmillan.

Helfrich, S. (2014). Common goods do not simply exist: They are created. http://wealthofthecommons.org/essay/ common-goods-don\%E2\%80\%99t-simply-exist-\%E2\%80\%93-they-are-created (Accessed on 11.6.2018).

Hill, R., Dyer, G. A., Lozada-Ellison, L. M., Gimona, A., Martin-Ortega, J., Munoz-Rojas, J., \& Gordon, I. J. (2015). A social-ecological systems analysis of impediments to delivery of the Aichi 2020 targets and potentially more effective pathways to the conservation of biodiversity, Global Environmental Change, 34, 22-34. https://doi.org/10.1016/j.gloenvcha.2015.04.005.

Jung, Y. S. (2016). Share of theory, reality, and possibility, The Korean Association for Environmental Sociology, 18(2), 205-214. 
Kaivanto, K. (2018). Community-level natural resource management institutions: A noncooperative equilibrium example. International Journal of the Commons, 12(1), 548-572. http://doi.org/10.18352/ijc.847.

Kim, H-S. \& Jung, C-S. (2016). Study on understanding and application of global code of ethics for tourism for sustainable growth of sport tourism: With focus on the PyeongChang 2018 Olympic Winter Games, Philosophy of Movement: Journal of Korean Philosophic Society for Sport and Dance, 24(1), 73-90. http://kiss.kstudy.com/thesis/thesis-view.asp?key=3429089

Kim, K. \& Kwon, S. (2016). Community-based sustainable use of environment: A case of Jeju-Haenyeo's commons resource management, Journal of The Korean Association of Regional Geographers, 22(1), 49-63.

Kim, S. (2014). A theoretical review on the reconstruction of the commons: A reinterpretation of Garrett Hardin's 'The Tragedy of the Commons' model through the theory of space by Henry Lefebvre, MARXISM, 11(3), 172-201.

Kip, M. (2015). Moving beyond the city: Conceptualizing urban commons from a critical urban studies perspective, In Dellenbaugh, M., Kip, M., Bienioik, M., Mueller, A. K., \& Schwegmann, M. (eds), Urban commons: Moving beyond state and market. Switzerland: Birkhäuser - De Gruyter, 42-59.

Kwon, S. (2012). Neoliberalizing water: Commodification debate and their making in Korea, Journal of the Economic Geographical Society of Korea, 15(3), 358-375.

Lee, E., Jung, C. S. \& Lee, M. K. (2014). The potential role of boundary organizations in the climate regime, Environmental Science \& Policy, 36, 24-36.

Lee, L. Y. (2009). Sense of community and its relationship with exterior spatial composition in apartment complex, Doctoral thesis of Chonnam National University.

Lee, S. H. \& Kim, Y. P. (2011). A comparative study on the conservation of rice terraces as cultural landscapes in Korean and Japanese rural areas, Journal of the Korean Institute of Forest Recreation, 15(2), 1-14.

Mansbridge, J. (2014) The role of the state in governing the commons, Environmental Science \& Policy, 36, 8-10.

McGrath, D. G., Almeida, O. T. \& Merry, F. D. (2007). The Influence of Community Management Agreements on Household Economic Strategies: Cattle Grazing and Fishing Agreements on the Lower Amazon Floodplain. International Journal of the Commons, 1(1), 67-88. http://doi.org/10.18352/ijc.54

Merino, L. \& Cendejas, J. (2017). Peace building from a commons perspective. International Journal of the Commons, 11(2), 907-927. http://doi.org/10.18352/ijc.773.

Nkoka, F., Veldwisch, G. J. \& Bolding, A. (2014). Organizational modalities of farmer-led irrigation development in Tsangano District, Mozambique, Water Alternatives, 7(2), 414-433.

Ostrom, E. (1990). Governing the commons: The evolution of institutions for collective action, Cambridge: Cambridge University Press.

Ostrom, E. (1998). A behavioural approach to the rational choice theory of collective action: Presidential address, American Political Science Association, 92(1), 1-22.

Poteete, A., Janssen, M. \& Ostrom, E. (2010). Working together: Collective action, the commons and multiple methods in practice, Princeton: Princeton University Press.

Polanyi, K. (1957). The great transformation, Boston: Beacon Press Boston. https://www.worldcat.org /title/great-transformation/oclc/317457654.

Son, H. \& Kim, S. (2016). Developing the tourism resources of agricultural heritage by values, Northeast Asia Tourism Research, 12(3), 39-58.

Steers, R. M. (1991). Introduction to organizational behavior ( $2^{\text {nd }}$ ed), Glenview, Ill: Scott, Foresman.

Thiel, A., Elias Adamseged, M. \& Baake, C. (2015). Evaluating an instrument for institutional crafting: How Ostrom's social-ecological systems framework is applied, Environmental Science \& Policy, 53, B, $152-164$.

Van Laerhoven, F. \& Ostrom, E. (2007). Traditions and trends in the study of the commons, International Journal of the Commons, 1(1), 3-28.

Wall, D. (2014). The Sustainable Economics of Elinor Ostrom: Commons, contestation and craft. New York \& London: Routledge. International Journal of the Commons, 8(2), 686-687. http://doi.org/10.18352/ijc.544.

Yu, D., Anderies, J. M., Lee, D. \& Perez, I. (2014). Transformation of resource management institutions under globalization: The case of songgye community forests in South Korea, Ecology and Society, 19(2), 2.

Yun, S. J. (2006). The dissolving process of village pasture commons in Jeju Island and its social and ecological implication, The Korean Rural Sociological Society, 16(2), 45-88.

*** Cultural Heritage Administration (2014). A study on the preservation and utilization plan of a national scenic spot, 21-25. http://www.prism.go.kr/homepage/entire/retrieveEntireDetail.do;jsessionid=147B3A3CE85463D39F797 CD93CD96A8E.nodeo2? cond_research_name=\&cond_research_start_date=\&cond_research_end_date $=\&$ research_id $=1550000-201400002 \&$ pageIndex $=526 \&$ leftMenuLevel $=160$.

*** Cultural Heritage Administration. (2016). Study on preservation management of scenic beauty, 32-33. https://www.cha.go.kr/cop/bbs/selectBoardArticle.do;jsessionid=111n4HXIs1rU2XPeGRnIr2HTBoFg7 Nv5Mg4m5rVAQmo7MPcVoXFn8gBaFx5HVlZ1.new-was_servlet_engine1?nttId=59669\&bbsId= BBSMSTR_1021\&pageUnit $=10 \&$ searchCnd=tc\&searchWrd $=\& \operatorname{ctgryL} \mathrm{Lrcl}=\& \operatorname{stgryMdcls}=\& \operatorname{ctgrySmcls}=\&$ ntcStartDt=\&ntcEndDt=\&searchUseYn=Y\&mn=NS_01_01.

Submitted:

06.08.2019
Revised:

14.02.2020
Accepted and published online 20.02.2020 